\title{
Raising the Bar on the Foreign Portfolio to 25 Per CENT: STRATEGIC IMPLICATIONS FOR SOUTH AFRICAN INVESTORS
}

\author{
David John Bradfield \\ Department of Statistical Sciences, University of Cape Town
}

Brian Munro

Cadiz Asset Management

Accepted: April 2015

\begin{abstract}
Regulation 28 of the Pension Funds Act now permits an increased allocation of 25 per cent to foreign investments. The regulation previously only permitted a 20 per cent allocation. Establishing the optimal foreign allocation for South African portfolio managers given the 25 per cent upper bound is an important consideration for strategic portfolio planning. In this paper we consider two methodological approaches to establish a strategic foreign allocation weight. Our first approach considers the strategic role of foreign investment in South African global balanced portfolios by using a mean-variance efficient frontier framework over a long-term period. We also implement a second assessment methodology that utilises a nonparametric procedure. Both the mean-variance and the non-parametric methodology yield compelling evidence for the foreign allocation to be set at the maximum allowable bound of 25 per cent.
\end{abstract}

Key words: foreign investment, efficient frontier, non-parametric optimisation, portfolio construction, asset allocation

JEL: G110

\section{$1 \quad$ Introduction}

Regulation 28 of the Pension Funds Act as of July 2011 now permits South Africans to allocate 25 per cent of their pension funds to foreign investments as well as an additional 5 per cent to other African-country asset classes (see the Financial Services Board website: www.fsb.co.za). According to the previous version of Regulation 28 a South African pension fund could invest a maximum of 20 per cent in foreign asset classes.

Previous research in South Africa (prior to July 2011 when the previous regime of Regulation 28 constrained foreign investment to only 20 per cent) shows that it was optimal to have allocated the entire 20 per cent to foreign assets (see Bradfield, Munro, Silberman \& Hendricks, 2010). Our objective in this paper is to quantify a strategic allocation to the foreign portfolio component given the recent relaxation of the foreign investment to 25 per cent.

Our first approach considers the strategic role of foreign investment in South African global balanced portfolios by utilising a mean-variance efficient frontier framework over the relatively long-term dating back to 1971, thus encapsulating a variety of economic regimes. Our approach is to establish the allocation to foreign assets across the entire risk spectrum of the efficient frontier. Additionally we further generate the efficient frontier excluding the foreign assets and then superimpose the efficient frontier which includes the foreign assets in order to assess how foreign assets have impacted the shape of the efficient frontier. Furthermore we provide details of what the foreign allocation weights were across the risk spectrum of efficient portfolios.

One well known criticism of our approach adopted here, regarding potential inferences for the future, is that the efficient frontier framework relies on point estimates only, thus does not accommodate for the reliability of these estimates. To this point, Michaud (1989) argues that mean-variance optimizers often tilt in the direction of the estimation errors - and refers to them as estimation error maximisers. Best and Grauer (1991) also show that the results of the optimisation process is highly sensitive to inputs, and any slight change to the inputs of the optimisation may 
lead to significant changes in the results. Additionally the mean-variance framework relies on the assumption that returns are normally distributed, thus does not cater for any skewness features. We thus also include a second assessment methodology that follows the methodology of Swartz (2004) and Munro and Silberman (2008). This methodology utilises a non-parametric optimisation technique based on historical data and importantly requires no distributional assumptions regarding the underlying return series.

This article is organized as follows: Section 2 contains a discussion of relevant literature; Section 3 discusses the two methodologies used in the empirical section; Section 4 outlines the results of the two empirical analyses and finally in Section 5 concluding arguments are summarized.

\section{Literature review}

There have been numerous academic studies in the literature on international diversification, however in this section we focus on the studies that have particular relevance to the objectives of this paper. These studies will be discussed, firstly, from an international perspective, followed by South African-centric studies.

\subsection{International studies}

The seminal work of Markowitz (1952, 1959) paved the way for a practical framework for establishing the benefits of diversification. Subsequently the benefits of international diversification have been documented by researchers over several decades (to name a few see, French \& Porterba, 1991; Obstfeld, 1994; Cosset \& Suret, 1995; Harvey, 1995; Novomestky, 1997; De Roon, Nijman \& Werker, 2001; Li, Sarkar \& Wang, 2003; Chiou, 2009; Bouslama \& Ouda, 2014). Many of these studies build on the pioneering work of Markowitz (1952), which shows how combining uncorrelated assets can reduce the average volatility of a portfolio.

Additionally many studies have focused on the attractiveness of emerging markets for international diversification in place of investment in developed markets. These studies are motivated by the typically lower correlations emerging markets have with developed markets (see for example, Errunza, 1977; Speidell \& Sappenfield, 1992; Harvey, 1995; Kohers, Kohers \& Pandey, 1998; Lagoarde-Segot \& Lucey, 2007; Gupta \& Donleavy, 2009).

A further competing phenomenon that has been frequently observed in the international literature is referred to as the "home-bias" effect, whereby investors invest largely in their home countries' stocks (see for example French \& Poterba, 1991; Tesar \& Werner 1995; Heathcote \& Perri, 2007; Berrill \& Kearney, 2008; Sendi \& Bellalah, 2010 to name a few). Berrill and Kearney (2008) point out that the extent to which investors diversify internationally remains less than theory predicts as they tend to hold the majority of their financial portfolios in domestic rather than international assets.

An important issue however that has recently attracted attention is whether international diversification benefits are still substantial given the evolution of the integration of world markets and the consequent rise in correlations. This topic has attracted considerable attention over the last few decades (see for example, Divecha, Drach \& Stefek, 1992; DeFusco, McLeavey, Pinto \& Runkle, 1996; Michaud, Bergstrom, Frashure \& Wolahan, 1996; Meric \& Meric, 1997). More recently Li et al. (2003) showed that even though markets were becoming more integrated, this integration does not eliminate the benefit of diversifying into emerging markets.

One of the few studies that has attempted to establish a foreign allocation weight from a US investor perspective is that of Heathcote and Perri (2007). They find their equilibrium model results in a portfolio consisting of 80 per cent domestic (US) and 20 per cent foreign (non-US) investment. Furthermore they point out that over the period 1990-2004 foreign assets accounted for, on average 25 per cent of the total value of the assets owned by U.S. residents.

The purpose of our study is primarily to establish an optimal allowable investment allocation to developed markets from an emerging market perspective, in particular the South African equity 
market. In the subsection below we briefly consider the literature on this topic from a South African investor perspective.

\subsection{South African studies}

Early work by Van den Honert (1983), Van den Honert and Affleck-Graves (1985), Barr (1986), Barr and Affleck-Graves (1987), Bhana (1986,), Patrick and Ward (1996) and Swart (1999) demonstrated that South Africans could have derived substantial benefits by including foreign securities in their portfolios.

More recently Swart (2004) concludes that a simple rule of allocating 30 per cent to local assets and 70 per cent to foreign assets could be used as a starting point for long-term investment strategies. Furthermore De Beer and Pretorius (2012) conclude that on the basis of their study there is still scope for South Africans to diversify their portfolios internationally, but argue that the correlations are lower with emerging markets, suggesting instead diversification into emerging markets.

When legislation only permitted 20 per cent to foreign allocation, Bradfield et al. (2010) put forward evidence that it was optimal to allocate the entire 20 per cent limit to foreign investment. This conclusion was based on several empirical methodologies including a sensitivity analysis across a range of varying economic regimes. On almost every occasion it was optimal to have had the full 20 per cent invested abroad.

Van Heerden and Koegelenberg (2013) recently conducted a South African-centric study that considered 7 different portfolio construction approaches and tested the hypothesis of whether domestic-only funds would significantly out-perform foreign-allocation funds with a maximum foreign allocation of 25 per cent permitted. They considered 10-, 20- and 30-year investment horizons and found that domestic-only portfolios significantly out-performed foreign-allocation ones over the 10-year investment period. They conclude however "Over the longer investment periods (20- and 30-year periods) mixed results were obtained, but it seems that the majority of optimisation strategies lean towards foreign-allocation portfolios when the investment horizon is increased." (see Van Heerden \& Koegelenberg, 2013:51). In contrast, our focus is on quantifying a strategic allocation to the foreign allocation given the 25 per cent maximum constraint.

\section{Methodology}

\subsection{Mean-Variance efficient frontier framework}

Our formulation for obtaining efficient frontiers in the mean-variance setting closely follows the methodology outlined by Sharpe (1970). As with Sharpe (1970) we considered the following objective function to find the set of efficient portfolios:

$\begin{array}{lll}\text { Minimize } & -\lambda E_{p}+\sigma_{p}^{2} & \text { for all possible } \lambda \geq 0 \\ \text { Where } & \sigma_{p}^{2}=X^{\prime} \Sigma X & \end{array}$

Subject to the constraints:

$1 \sum_{i=1}^{N} X_{i}=1$

that is, the entire portfolio must be invested.

$2 X_{i} \geq 0 \quad$ for all $\mathrm{i}=1,2, \ldots, \mathrm{N}$

that is, no assets may be held in negative quantities thus no short sales are permitted.

Note that $X_{i}$ is the proportion of funds invested in asset $i$, and a portfolio is represented by a vector of investment weights:

$X^{\prime}=\left(X_{1}, X_{2}, \ldots, X_{N}\right)$;

$E_{p}$ is the expected return on the portfolio; 
$\sigma_{p}$ is the standard deviation or volatility of return on the portfolio;

$\Sigma$ is the variance-covariance matrix of returns

$\lambda$ is a parameter varying between 0 and $\infty$;

Solution of the above model was obtained by using the following steps:

1 Assign a numeric value to $\lambda$ between 0 and $\infty$;

2 Solve for the $X_{i}{ }^{\prime}$ s;

3 Change the value of $\lambda$ and repeat.

The above model was implemented using MATLAB.

\subsection{Non-parametric asset allocation framework}

The framework utilised here follows the methodology of Swartz (2004) and Munro and Silberman (2008). The framework is based on identifying the portfolios that most often achieve specified absolute return (inflation-based) targets over three year investment periods. We henceforth refer to the inflation-based target as the "CPI+" return target. The approach is to simulate fifty thousand portfolios comprising different asset weights and to assess their performances relative to the specified $\mathrm{CPI}+$ targets ranging from $\mathrm{CPI}+1$ per cent to the $\mathrm{CPI}+8$ per cent target over rolling 3year periods. Note that a 3-year investment horizon was chosen to be consistent with Swartz (2004) and Munro and Silberman (2008) as well as many of the absolute return fund mandates of South African unit trusts. Thereafter weights of the top 5 per cent that yielded the maximum frequency/probability of outperforming the pre-specified absolute return targets over the three year investment periods are averaged and reported.

A step-by-step approach to the methodology is outlined below.

Using a simulation process:

- Randomly generate 50000 portfolio weights for the different asset classes ranging from 0 to 100 per cent: Noting that for each portfolio the weights sum to 100 per cent.

- For each portfolio calculate all 3-year annualised returns from January 1971 to December 2010 and compare the returns to the CPI+ targets for the same periods.

- $\quad$ Determine the probability of each portfolio outperforming the CPI+ target over the entire 40 years.

- Select the top 5 per cent of portfolios that have the highest frequency/probability of outperforming the CPI+ target.

- Determine the average asset weights for each asset class of these top 5 per cent of portfolios.

- The entire procedure above is then repeated for the various CPI + targets.

The above process is summarised in the flow-diagram shown in Exhibit 1.

4 Data

The asset classes include domestic equities (proxied by the All Share index), domestic bonds (proxied by the All Bond Index), domestic cash (proxied by 3-month Treasury-bills), domestic property (proxied by a combination of Property Unit Trust Index, Property Loan Stock Index and Listed Property Index to obtain a dataset for the full period), foreign equities (proxied by the MSCI Global Equity Index), foreign bonds (proxied by the JP Morgan World Bond Index), foreign cash (proxied by US 3-month treasury bills). Monthly total return data were obtained from I-Net Bridge. The period over which the data spanned January 1971 to December 2010. 


\section{Exhibit 1}

Flow diagram of the non-parametric procedure

1. Simulate 50000 different combinations of asset mixes.

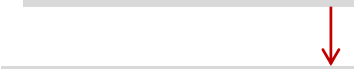

2. Select one of the 50000 asset mixes, without replacement

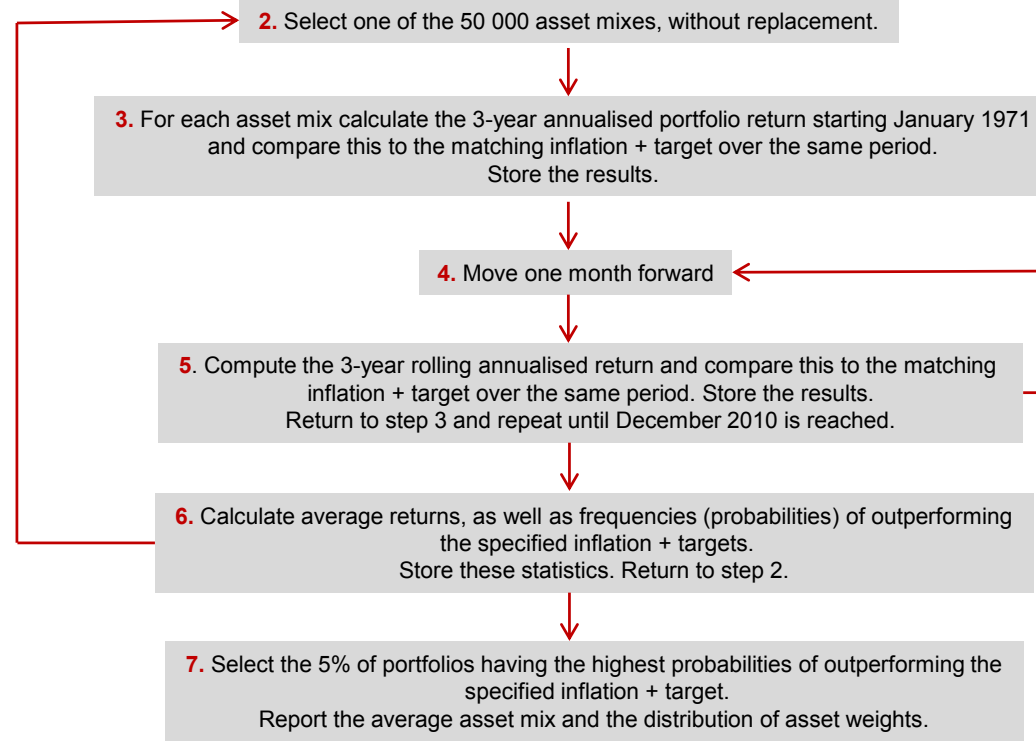

The vector of return inputs for these assets is found in Table 1 below together with the annualised standard deviations of these returns alongside. The correlations between the assets are found in Table 2.

Table 1

Returns and risks of major asset classes (Jan 1971 to Dec 2010)

\begin{tabular}{|l|c|c|}
\hline \multicolumn{1}{|c|}{ Asset } & Return \% p.a. & Volatility \% p.a. \\
\hline Bonds & 12.2 & 8.3 \\
\hline Property & 16.1 & 19.2 \\
\hline Equity & 19.6 & 22.3 \\
\hline Foreign cash (rands) & 11.7 & 13.7 \\
\hline Foreign bonds (rands) & 14.3 & 14.4 \\
\hline Foreign equity (rands) & 16.2 & 17.7 \\
\hline
\end{tabular}

Source: BNP Paribas Cadiz Securities

From Table 1 we note that the highest return asset class is local equity (with an annualised return of 19.6 per cent) and the lowest volatility asset class is local bonds (with an annualised volatility of 8.3 per cent).

Table 2

Correlation matrix between major asset classes (Jan 1971 to Dec 2010)

\begin{tabular}{|l|c|c|c|c|c|c|}
\hline \multicolumn{1}{|c|}{ Asset class } & Bonds & Property & Equity & $\begin{array}{c}\text { Foreign } \\
\text { cash } \mathbf{R}\end{array}$ & $\begin{array}{c}\text { Foreign } \\
\text { bonds R }\end{array}$ & $\begin{array}{c}\text { Foreign } \\
\text { equity } \mathbf{R}\end{array}$ \\
\hline Bonds & 1 & & & & \\
Property & 0.30 & 1 & & & \\
Equity & 0.25 & 0.46 & 1 & & \\
\hline Foreign cash (rands) & -0.23 & -0.16 & -0.07 & 1 & & \\
Foreign bonds (rands) & -0.13 & -0.13 & -0.06 & 0.87 & 1 & \\
Foreign equity (rands) & -0.04 & 0.16 & 0.35 & 0.56 & 0.60 & 1 \\
\hline
\end{tabular}

Source: BNP Paribas Cadiz Securities 
Table 2 showing the correlation matrix reveals that both foreign bonds and foreign cash have negative correlations with our local equity market highlighting their relative attractiveness from a diversification perspective. We point out that it is primarily due to the embedded currency effect that the negative correlations exist. Whilst foreign equity also has the embedded currency effect, its underlying dollar series has a strong positive correlation with our local equity thus dampening the ultimate correlation when expressed in rand terms.

\section{Empirical results}

\subsection{Efficient frontier analysis}

We begin our assessment of domestic and foreign assets by performing a mean-variance efficient frontier analysis. For this analysis, we consider one-period performance from January 1971 to December 2010. We used this extensive period as our aim is to establish strategic long-term insights regarding the role of foreign assets.

Our methodology in this section for obtaining the efficient frontiers follows the methodology outlined in section 3.1 .

Figure 1 that ensues shows the resulting 40-year historical efficient frontier including the six asset classes in Table 2 in the opportunity set of investable assets. Additionally, points representing efficient portfolios at equally spaced risk intervals along the efficient frontier, are also shown (the dots on the efficient frontier). The compositions of these efficient portfolios are shown in Table 3 that follows thereafter.

Figure 1

Unconstrained efficient frontier including foreign assets (Jan 1971 to Dec 2010)

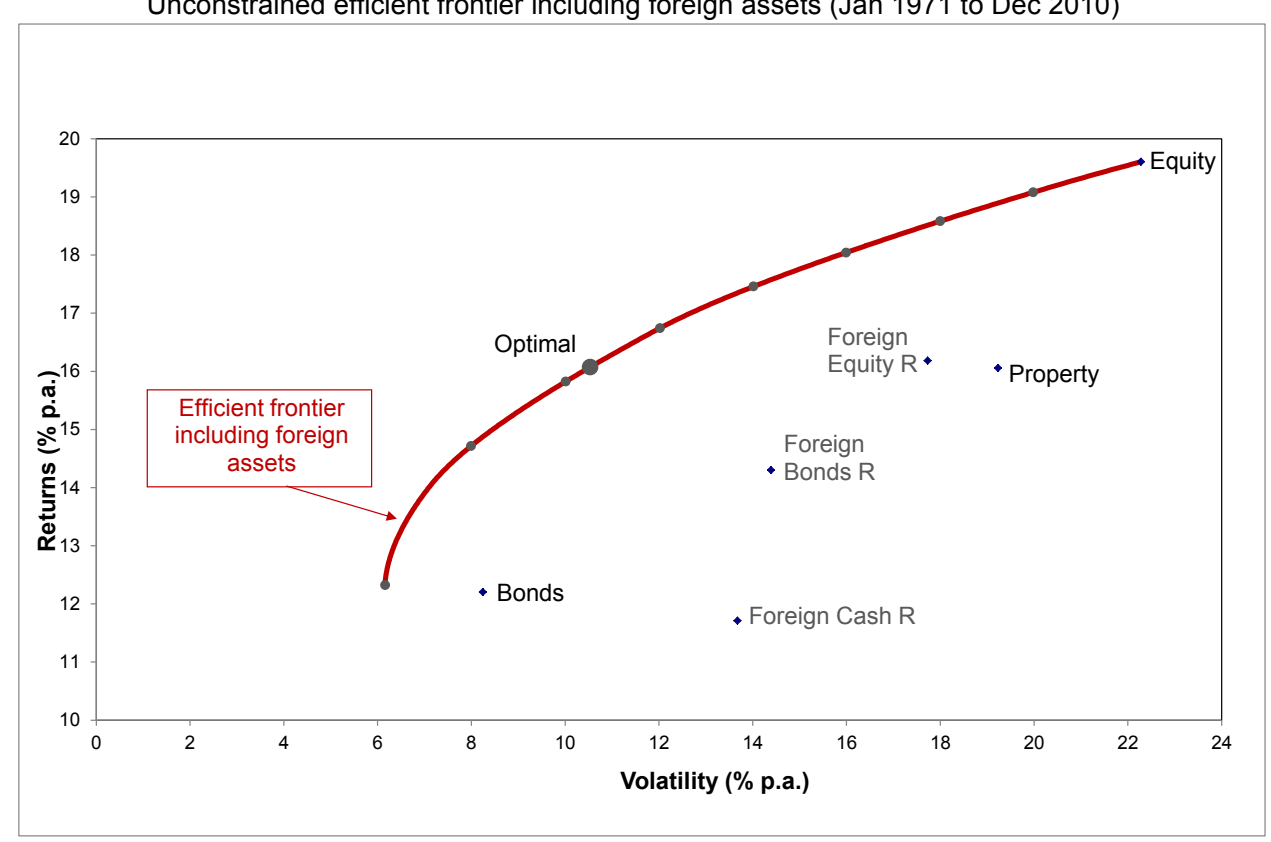

Figure 1 shows the relative positions of the six asset classes together with the resulting efficient frontier and the optimal portfolio for the period January 1971 to December 2010. Table 3 below shows the compositions of the efficient portfolios at the equally spaced risk positions together with the total investment weight in foreign assets in the last column. 
Table 3

Portfolio compositions at equal risk points on the efficient frontier (Jan 1971 to Dec 2010)

\begin{tabular}{|c|c|c|c|c|c|c|c|}
\hline Total risk & Bonds & Property & Equity & $\begin{array}{c}\text { Foreign } \\
\text { cash } R\end{array}$ & $\begin{array}{l}\text { Foreign } \\
\text { bonds } R\end{array}$ & $\begin{array}{l}\text { Foreign } \\
\text { equity } R\end{array}$ & Foreign \\
\hline 6.2 & $63 \%$ & $5 \%$ & $1 \%$ & $31 \%$ & $0 \%$ & $0 \%$ & $31 \%$ \\
\hline 8.0 & $36 \%$ & $10 \%$ & $19 \%$ & $0 \%$ & $35 \%$ & $0 \%$ & $35 \%$ \\
\hline 10.0 & $16 \%$ & $14 \%$ & $30 \%$ & $0 \%$ & $40 \%$ & $0 \%$ & $40 \%$ \\
\hline 10.5 & $11 \%$ & $15 \%$ & $33 \%$ & $0 \%$ & $41 \%$ & $0 \%$ & $41 \%$ \\
\hline 12.0 & $0 \%$ & $16 \%$ & $41 \%$ & $0 \%$ & $43 \%$ & $0 \%$ & $43 \%$ \\
\hline 14.0 & $0 \%$ & $9 \%$ & $56 \%$ & $0 \%$ & $33 \%$ & $2 \%$ & $35 \%$ \\
\hline 16.0 & $0 \%$ & $4 \%$ & $67 \%$ & $0 \%$ & $23 \%$ & $5 \%$ & $29 \%$ \\
\hline 18.0 & $0 \%$ & $0 \%$ & $78 \%$ & $0 \%$ & $14 \%$ & $9 \%$ & $22 \%$ \\
\hline 20.0 & $0 \%$ & $0 \%$ & $86 \%$ & $0 \%$ & $2 \%$ & $12 \%$ & $14 \%$ \\
\hline
\end{tabular}

Note: The optimal portfolio is shown in bold

Source: BNP Paribas Cadiz Securities

Table 3 quantifies the extent of the allocation to the foreign portfolio (shown in the last column) across the range of risks along the efficient frontier. From the lowest risk portfolio of 6.2 per cent p.a. (shown in column 1), to immediately prior to the relatively high portfolio risk of 18 per cent p.a. (actually 17.5 per cent p.a.), we find that the allocation to the foreign portfolio is in excess of 25 per cent. Only for efficient portfolios having risks of 17.5 per cent p.a. or more do we find allocations to foreign assets less than 25 per cent where more local equity is required to reach the higher return targets. We surmise that few pension funds would have the appetite for these high levels of risk, suggesting a 25 per cent allocation to the foreign portfolio would be a strategic choice for most pension funds.

Figure 2 below confirms the results in Table 3 by highlighting the portion of the efficient frontier where the foreign portfolio exceeds 25 per cent.

Figure 2

Demarking the risk range along the efficient frontier where foreign assets exceed 25 per cent (Jan 1971 to Dec 2010)

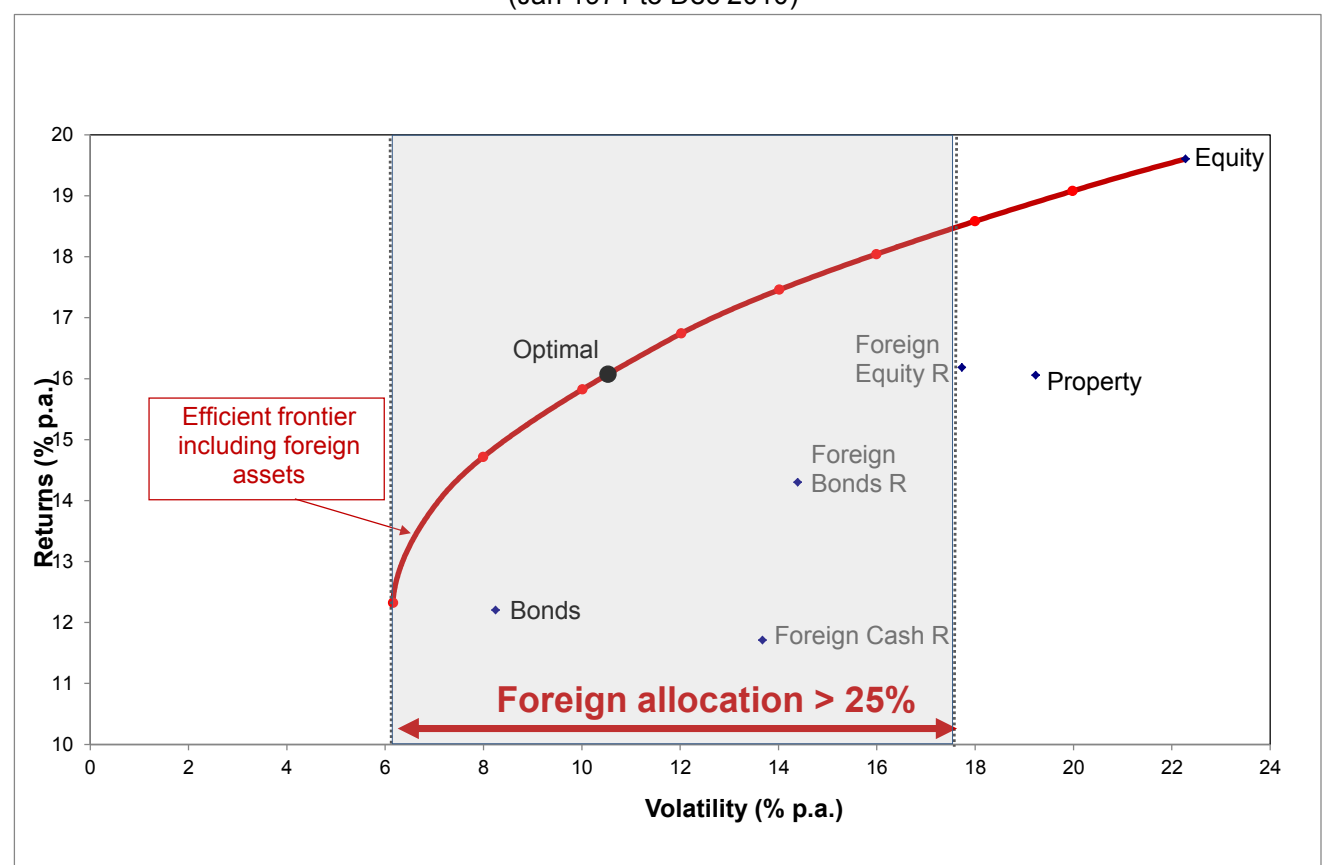


In the context of our objective of establishing a strategic weight to foreign equity (given the 25 per cent allocation constraint), Figure 2 demarcates the portion of the efficient frontier where portfolios have an allocation to foreign assets in excess of 25 per cent. As with Table 3 it turns out that all efficient portfolios, starting with the minimum risk portfolio (MRP) and moving along the efficient frontier to a 17.5 per cent p.a. risk level, have a foreign allocation in excess of 25 per cent. Only in risk regions in excess of 17.5 per cent does the foreign allocation drop to less than 25 per cent. Figure 2 also reveals that the optimal portfolio is found within this demarcated area and has an allocation to foreign assets of 41 per cent (as seen in Table 3 ).

To establish the impact that foreign assets have had on the shape of the efficient frontier we consider the efficient frontier excluding foreign assets together with the efficient frontier including foreign assets in Figure 3 below.

Figure 3

Unconstrained efficient frontiers - with and without foreign assets (Jan 1971 to Dec 2010)

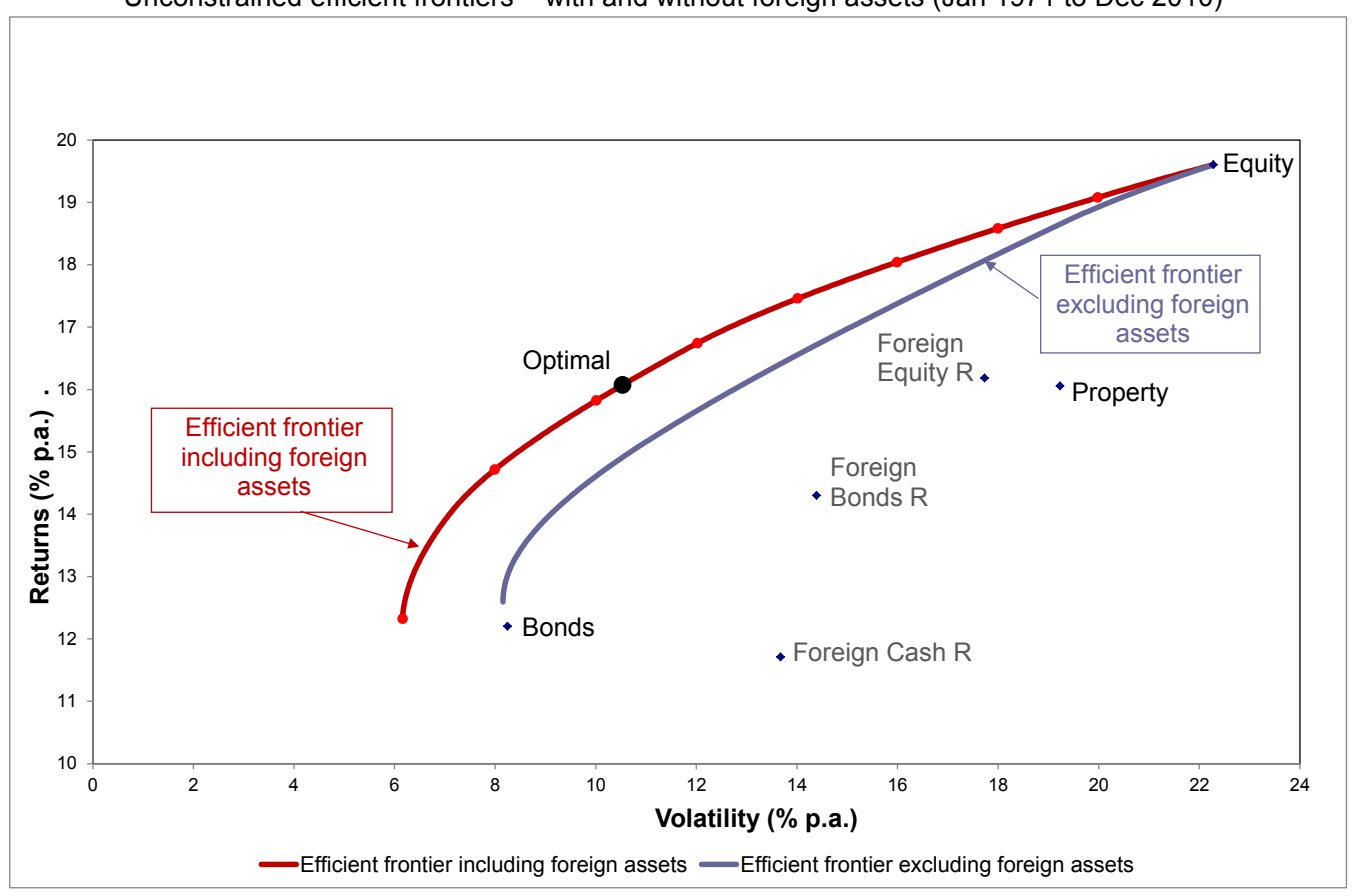

Source: BNP Paribas Cadiz Securities

From Figure 3 it is clear that the inclusion of foreign assets has resulted in the efficient frontier not only moving significantly to the left (i.e. risk reducing) but also upward (i.e. return enhancing). This comparison of the efficient frontiers is supportive of the enhancing role foreign assets have played and highlights the strategic importance of foreign assets in our local portfolio design.

The likely explanation for this high allocation to foreign assets across this broad risk range is evident when one considers the benefits of diversification. Local portfolios benefit from returns of foreign bonds and foreign cash (both having negative correlations to local equity) arriving at times when the rest of the portfolio is performing poorly. Notable in Table 3 is that the efficient portfolios contain literally no foreign equity, but instead have a relatively large allocation to foreign bonds and foreign cash across the risk spectrum. Interestingly however from Table 1 we see that foreign equity has a higher mean return than foreign bonds and foreign cash. Clearly foreign equity returns arrive in synchronisation with local equities, but the local ones are expected to be somewhat higher, and are thus preferred by the optimisation process over foreign equity for this reason. The returns of foreign bonds however tend to arrive when the rest of the portfolio is performing poorly, and for this reason are preferred to foreign equity by the optimisation process. 
One criticism of our approach adopted here, regarding potential inferences is that the efficient frontier framework relies on point estimates only, thus does not accommodate for the uncertainty around these estimates.

We address this criticism briefly by adopting a framework that not only avoids point estimates but does also not rely on any prior assumption on the distribution of returns (termed the nonparametric optimisation approach). In essence this approach establishes which asset blends for example, most often in history meet the specified return targets most consistently.

\subsection{Non-parametric asset allocation analysis}

The framework utilised here follows the methodology outlined in detail in section 3.2.

The framework is based on identifying the portfolios that most often achieves specified absolute return (inflation-based) targets over three year investment periods. As discussed in section 3.2 the approach is to simulate fifty thousand portfolios comprising different asset weights and to assess their performances relative to the specified absolute return targets over rolling 3-year periods. Thereafter weights of the top 5 per cent that have yielded the maximum frequency/probability of outperforming the pre-specified absolute return targets over the three year investment periods are averaged and reported.

Figure 4 that follows shows the local/foreign allocation weights most consistently breaching the absolute return targets specified on the horizontal axis over a 3-year investment horizon. These specified absolute return targets typically cover the range of "inflation+" targets mandated by unit trusts having absolute return mandates as well as institutional absolute return funds. Important to note is that the foreign assets have all been converted to our local currency (rands), thus they have the historical currency effect embedded in them.

Figure 4

Unconstrained local/foreign allocation weights that had the highest probability of outperforming Inflation + targets over a 3-year investment period (January 1971 to December 2010)

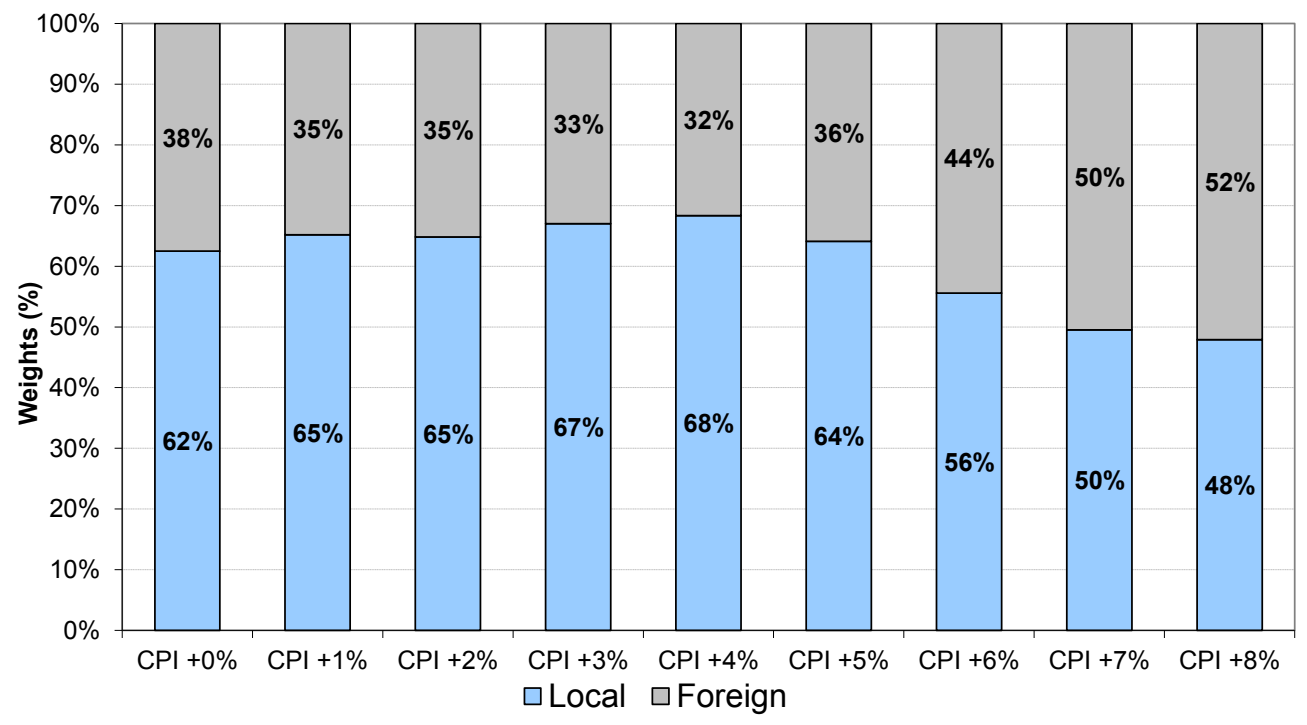

Source: BNP Paribas Cadiz Securities

From Figure 4 we see that over all return targets considered, it would have been optimal to have allocated at least the current maximum allowance of 25 per cent to the foreign portfolio. Interestingly the least allocation to the foreign portfolio is 32 per cent, occurring at a $\mathrm{CPI}+4$ per cent target. 
In Figure 5 we give a more detailed breakdown by asset class of the unconstrained Local/Foreign allocations found in Figure 4. Once more these asset class allocations had the best probability of outperforming CPI + targets over a 3-year investment period.

Figure 5

Detailed composition of Local/Foreign allocations by asset class weights (January 1971 to December 2010)

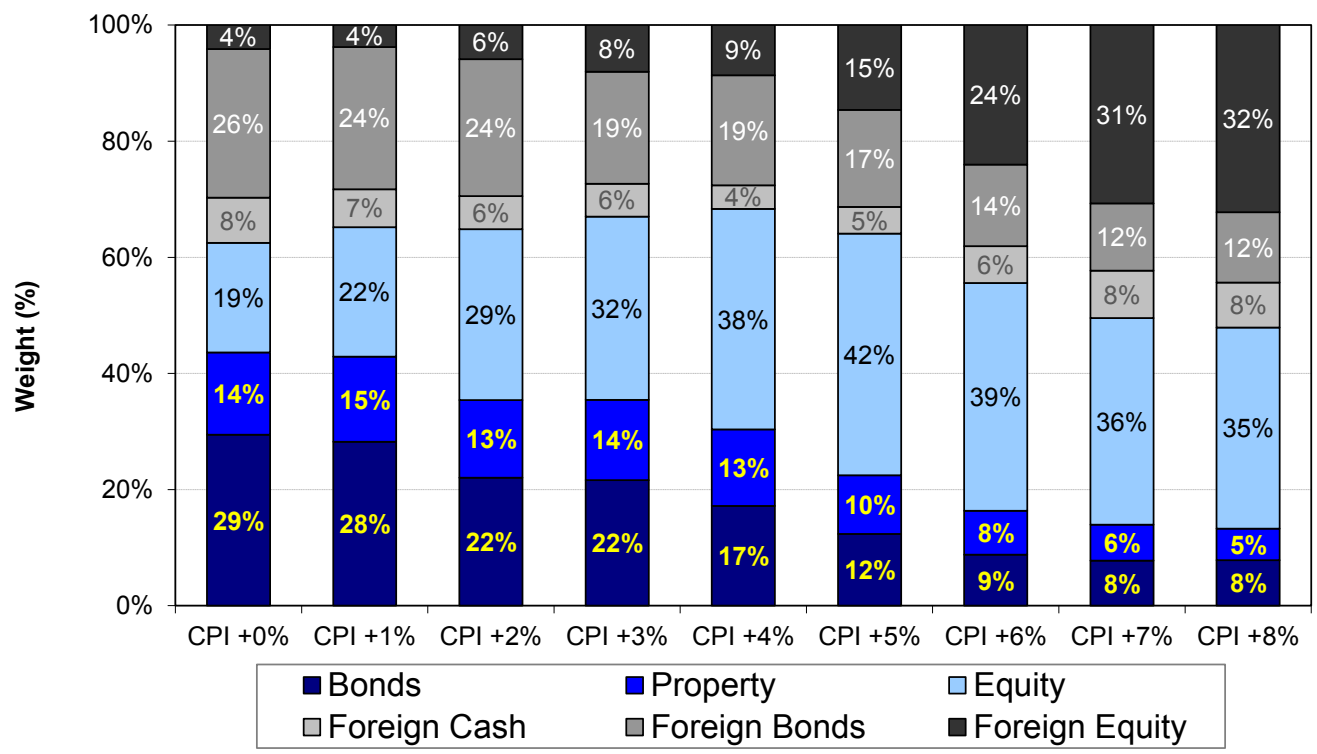

Source: BNP Paribas Cadiz Securities

The primary feature of Figure 5 is the increase in equity allocations (both local and foreign) with increasing $\mathrm{CPI}+$ targets required to meet the raised return targets. These increasing equity allocations typically occur at the expense of the bond allocations (in both the local and foreign sub-portfolios).

Together with the increasing demand for equity required by higher absolute return targets, one would expect that the probabilities of attaining these higher targets will diminish. Recall that the probabilities are obtained from the frequency of occurrences that the 3-year return for the optimal asset mix for the specified CPI+ target actually breached the target. Table 4 shows the probability of achieving the various absolute return targets generated by our non-parametric model.

Table 4

Probability of achieving various absolute return targets over 3 year rolling horizons (January 1971 to December 2010)

\begin{tabular}{|c|c|}
\hline \multicolumn{1}{|c|}{ CPI+ target } & Probability \\
\hline $\mathrm{CPI}+1 \%$ & 0.81 \\
\hline $\mathrm{CPI}+2 \%$ & 0.77 \\
\hline $\mathrm{CPI}+3 \%$ & 0.73 \\
\hline $\mathrm{CPI}+4 \%$ & 0.69 \\
\hline $\mathrm{CPI}+5 \%$ & 0.64 \\
\hline $\mathrm{CPI}+6 \%$ & 0.59 \\
\hline $\mathrm{CPI}+7 \%$ & 0.55 \\
\hline $\mathrm{CPI}+8 \%$ & 0.50 \\
\hline
\end{tabular}

Source: BNP Paribas Cadiz Securities

From Table 4 it is evident how the probabilities of achieving the absolute return targets diminish with increasing absolute return targets. Whilst there is approximately a 77 per cent chance of 
achieving a CPI +2 per cent target with the asset allocation depicted in Figure 3 (based on this history), there is only a 50 per cent chance of achieving the CPI +8 per cent target. This suggests that mandates at this high level would typically have only a half chance of being obtained.

Figure 6 gives an indication of the reliability of our resulting allocations for CPI +4 per cent over a 3-year investment time horizon. Figure 4 shows box-and-whisker plots of the distribution of the allocations to each asset class emanating from the top 5 per cent of portfolios that most consistently beat the $\mathrm{CPI}+4$ per cent target.

Figure 6

Distribution of the asset class weights that beat $\mathrm{CPI}+4$ per cent over a 3-year investment time horizon (January 1971 to December 2010).

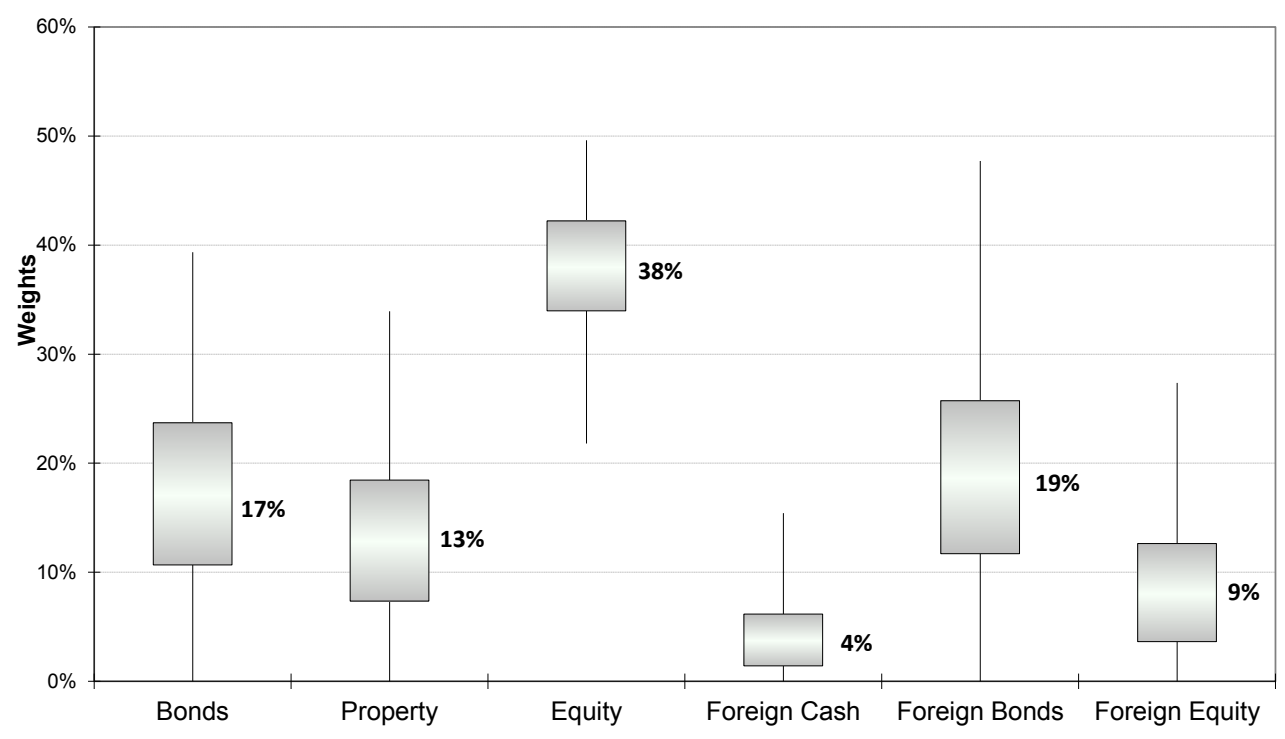

Source: BNP Paribas Cadiz Securities

The height of the "boxes" in Figure 6 show the interquartile ranges of the distribution for each asset class. Thus the taller the boxes, the more unreliable the allocation estimate and vice versa. The number alongside the box represents the average allocation weight to that particular asset class.

For the local asset allocations we see the taller "boxes" typically occur for bonds and property, suggesting that the choice of allocating between these 2 asset classes is less reliable. Thus they must to some extent have performed the role of being substitutable choices. A similar argument could be put forward for the allocation between foreign bonds and foreign equity.

We turn our attention to differing investment horizons to establish whether the compelling result of having 25 per cent foreign allocation persists over both longer and shorter investment time horizons. In Figure 7 we show the results for a CPI+4 per cent target only, but introduce more investment horizon scenarios. Figure 7 shows the optimal allocations for the 1-, 2-, 3-, 4-, and 5year investment horizons.

From Figure 7 we see that even over the shorter and longer investment horizons the nonparametric approach allocates in excess of 25 per cent to the foreign portfolio on each occasion. In fact the lowest allocation is for the 3-year time horizon (at 32 per cent in the foreign portfolio).

Of interest is the dominance of foreign bonds in the foreign portfolio (with the exception of the $\mathrm{CPI}+1$ per cent target where foreign equity dominates). Once more an explanation for why foreign bonds have dominated the optimal foreign portfolio is that our local equity market is negatively correlated with Foreign Bonds (having a correlation of -0.06 as seen in Table 2). This negative correlation is primarily due to the embedded currency effect which also has a negative correlation with our local equity market (of -0.11). However because Foreign Equity to some degree moves 
with local equity, the embedded currency effect is not that dominant in the foreign equity series (the correlation with local equity is instead moderately positive at 0.35 as seen in Table 2 ). Thus it is evident that a major benefit of the foreign portfolio is the embedded currency effect.

Figure 7

Unconstrained allocation weights that had the highest probability of outperforming inflation + targets over various investment horizons (January 1971 to December 2010)

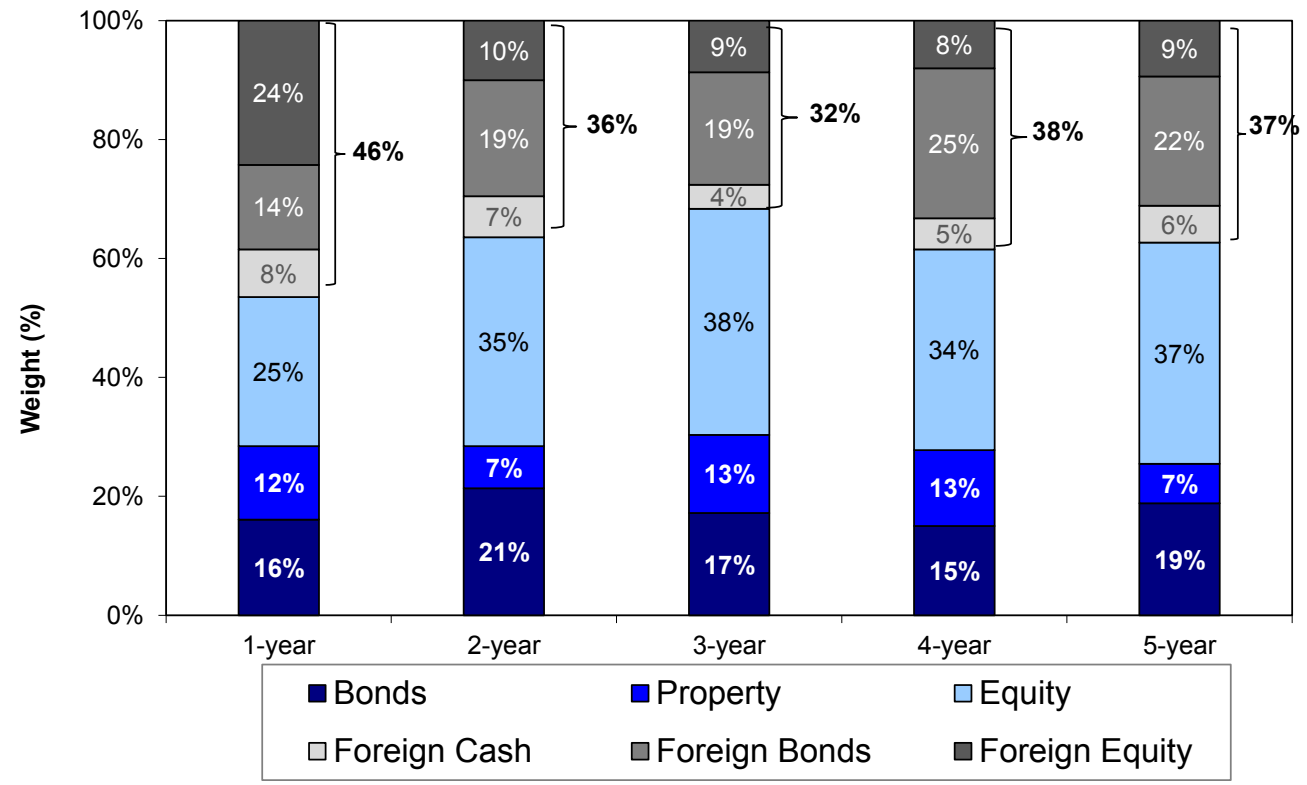

Source: BNP Paribas Cadiz Securities

Bradfield, Munro and Silberman (2011) conduct an analysis using conditional correlations and find that the currency has displayed favourable non-symmetric characteristics. This favourable feature is evident when one contrasts the behaviour of the currency's relationship to the ALSI when the ALSI is declining, versus to when it is rising. They argue that when the ALSI is declining, the currency has a significant negative correlation, but when it is rising the conditional correlation is positive. They argue that this is an attractive feature and one which managers would certainly want to take advantage of in their portfolios. As it turns out, investing in foreign assets embeds the currency effect which encompasses this relatively advantageous feature.

Table 5 that follows shows the probabilities of achieving the absolute return target $\mathrm{CPI}+4$ per cent over 1 year investment horizons through to 5 year investment horizons.

Table 5

Probability of achieving the $\mathrm{CPI}+4$ per cent target over various investment horizons (January 1971 to December 2010).

\begin{tabular}{|l|c|}
\hline \multicolumn{1}{|c|}{ Investment horizon } & Probability \\
\hline 1 year & 0.64 \\
\hline 2 year & 0.64 \\
\hline 3 year & 0.69 \\
\hline 4 year & 0.77 \\
\hline 5 year & 0.82 \\
\hline
\end{tabular}

Source: BNP Paribas Cadiz Securities

Notable in Table 5 is the extent to which the probability of achieving CPI +4 per cent increases with increasing investment horizons. One sees for example that the probability of achieving the absolute return targets increases from 0.64 for a 1 year horizon to 0.82 for a 5 year horizon. This 
result is intuitive suggesting that absolute return targets are more likely to be met the longer the investment horizon.

\subsection{Practitioner perspective}

Lastly we turn to the practitioners to establish what their perspectives on the foreign portfolio allocation are as reflected in their actual foreign holdings (as at September 2013). We consider the Alexander Forbes Large Manager Watch (AFLMW) which comprises the aggregate asset class holdings of the largest 10 pension funds. Table 6 shows these holdings.

Table 6

Average AFLMW asset allocation for domestic and global balanced funds (Sept 2013)

\begin{tabular}{|l|c|}
\hline \multicolumn{1}{|c|}{ Asset } & - \\
\hline Cash & Average allocation (\%) ------ \\
\hline Bonds & 9.9 \\
\hline Equity ex listed property & 44.2 \\
\hline Property & 2.8 \\
\hline Listed property & 2.6 \\
\hline Direct property & 0.2 \\
\hline Foreign assets & $\mathbf{2 7 . 0}$ \\
\hline
\end{tabular}

Source: Alexander Forbes Large Manager Watch

As one can see from the last row in Table 6 the aggregate foreign holdings are at 27 per cent. Because managers are only allowed to invest 25 per cent offshore it is clear that almost all the managers have done so and that the relative return differences between the foreign and local portfolio returns have resulted in the foreign portfolio weights drifting higher than the 25 per cent regulated. Importantly however, we see that these managers are also of the view that the strategic foreign portfolio weight should be placed at the regulated 25 per cent bound, which is consistent with our research findings here.

Thus our mean-variance efficient frontier analysis, the results of our non-parametric methodology, as well as the current holdings of the AFLMW managers all support the result that the strategic foreign allocation be set at the 25 per cent bound regulated by Regulation 28 .

\section{Conclusions}

We have summarised results from two different methodologies on the question of what percentage of assets should be held abroad from a strategic perspective: Our investigations give compelling evidence in support of maintaining the strategic allocation to foreign investment at the regulated bound of 25 per cent.

Our mean-variance efficient frontier analysis found that an unconstrained foreign allocation resulted in allocations to the foreign portfolio in excess of 25 per cent across the majority of the risk spectrum beginning with the minimum variance portfolio right up to a relatively high portfolio risk of 17.5 per cent p.a. Thereafter the foreign allocation dropped to below 25 per cent as risk targets were raised to higher levels.

The results of our non-parametric methodology targeting absolute return mandates based on a $\mathrm{CPI}+$ framework resulted in similar consistent conclusions. We found that for targets ranging from $\mathrm{CP}+1$ per cent to $\mathrm{CPI}+8$ per cent, all portfolios with the highest probability of achieving these targets had allocations to the foreign portfolio in excess of 25 per cent over 3-year investment horizons. Furthermore we considered the results over different investment horizons ranging from 1 -year to 5 -years for the CPI +4 per cent target. Our findings once more confirmed allocations to the foreign portfolio in excess of 25 per cent for all of these investment time horizons considered.

Portfolios in the AFLMW survey were also found to have an aggregate allocation at the 25 per cent bound (actually 26.7 per cent because of drift) confirming that practitioners seem to share the 
view of placing the foreign allocation at the regulated 25 per cent bound.

Whilst some may counter that the risk and return expectations of foreign assets are not as favourable as local assets, the less observable diversification benefit that the foreign allocation brings to local balanced portfolios (albeit through the embedded currency effect) cannot be ignored. When one takes this significant diversification benefit into account (as we have done in our study) the evidence is indeed compelling for the strategic foreign allocation to be raised to the 25 per cent bound.

Finally we point out a specific limitation of our study that it was based entirely on historical data. Should there be any structural changes to the relationships between the asset classes in future, one may reach different conclusions.

\section{Acknowledgements}

The authors would like to thank BNP Paribas Cadiz Securities for their support during the production of this paper.

This publication is based on research that has been supported in part by the University of Cape Town's Research Committee (URC).

\section{References}

BARR, G.D.I. 1986. International diversification after 1985 - The argument becomes stronger. South African Journal of Business Management, 17(3):139-142.

BARR, G.D.I. \& AFFLECK-GRAVES, J.F. 1987. Diversification in foreign assets - A comment. Journal for Studies in Economics and Econometrics, 11:95-113.

BERRILL, J. \& KEARNEY, C. 2008. Firm-level internationalisation and the home bias puzzle. Journal of Economics and Business, doi:10.1016/j.jeconbus.2010.02.002

BEST, M.J. \& GRAUER, R. 1991. On the sensitivity of mean-variance-efficient portfolios to changes in asset means: Some analytical and computational results. Review of Financial Studies, 4:315-42.

BHANA, N. 1986. International share portfolio diversification: Possible benefits for South African investors. South African Journal of Business Management, 17(3):162-168.

BOUSLAMA, O \& OUDA, O.B. 2014. International portfolio diversification benefits: The relevance of emerging markets. International Journal of Economics and Finance, 6(3):200-215.

BRADFIELD, D., MUNRO, B., SILBERMAN, K. \& HENDRICKS D. 2010. How much should we allocate to foreign investment? Cadiz Securities Quantitative Research Report.

BRADFIELD, D., MUNRO, B. \& SILBERMAN, K. 2011. Should we join the flight to emerging markets. Cadiz Securities Quantitative Research Report.

CHIOU, W.P.2009. Who benefits more from international diversification? Journal of International Financial Markets, Institutions and Money, 29.

COSSET, J. \& SURET, J. 1995. Political risk and the benefit of international portfolio diversification. Journal of International Business Studies, 26:301-318.

DE BEER, J. \& PRETORIUS, A. 2012. Is the case for international diversification still intact? Some evidence from return gaps and correlations. African Journal of Business Management, 6(35):9773-9782. DEFUSCO, R., MCLEAVEY, D.W., PINTO, J.E. \& RUNKLE, D.E. 2011. Quantitative investment analysis $\left(2^{\text {nd }}\right.$ ed. $)$ Wiley.

DE ROON, F.A., NIJMAN, T.E. \& WERKER, B.J. 2001. Testing for mean-variance spanning with short sales constraints and transaction costs: The case of emerging markets. Journal of Finance, 56:721-742.

DIVECHA, A.B., DRACH, G. \& STEFEK, D. 1992. Emerging markets: A quantitative perspective. Journal of Portfolio Management, 19(1):41-50.

ERRUNZA, V.R. 1977. Gains from portfolio diversification into less developed countries' securities: A reply. Journal of International Business Studies, 8(2):83-100.

FRENCH, K.R., \& POTERBA, J.M. 1991. Investor diversification and international equity markets. American Economic Review, 81:222-226. 
GUPTA, R. \& DONLEAVY, G.D. 2009. Benefits of diversifying investments into emerging markets with time-varying correlations: An Australian perspective. Journal of Multinational Financial Management, 19(2): 160-177.

HARVEY, C. 1995. Predictable risk and returns in emerging markets. Review of Financial Studies, 8: 773-816.

HEATHCOTE, J. \& PERRI, F. 2007. The international diversification puzzle is not as bad as you think, NBER Working Paper series, Working paper 13483.

KOHERS, T., KOHERS, G. \& PANDEY, V. 1998. The contribution of emerging markets in international diversification strategies. Applied Financial Economics, 8(5):445-454.

LAGOARDE-SEGOT, T., \& LUCEY, B.M. 2007. International portfolio diversification: Is there a role for the Middle East and North Africa? Journal of Multinational Financial Management, 17(5):401-416.

LI, K., SARKAR, A. \& WANG, Z. 2003. Diversification benefits of emerging markets subject to portfolio constraints. Journal of Empirical Finance, 10:57-80.

MARKOWITZ, H. 1952. Portfolio Selection. Journal of Finance, 7:77-91.

MARKOWITZ, H. 1959. Portfolio selection: Efficient diversification of investments. New York: John Wiley \& Sons.

MERIC, I. \& MERIC, G. 1997. Co-movements of European equity markets before and after the $1987 \mathrm{crash}$. Multinational Finance Journal, 1(2):137-152.

MICHAUD, R. 1989. The Markowitz optimization enigma: Is optimized optimal? Financial Analysts Journal, 45:31-42.

MICHAUD, R.O., BERGSTROM, G.L., FRASHURE, R.D. \& WOLAHAN, B. 1996. Twenty years of international equity financing. Journal of Portfolio Management, 23(1):9-27.

MUNRO, B \& SILBERMAN, K. 2008. Optimal asset allocation in different economic environments, Cadiz Securities Quantitative Research Report.

NOVOMESTKY, F. 1997. A dynamic, globally diversified, index neutral synthetic asset allocation strategy. Management Science, 43, 998-1016.

OBSTFELD, M. 1994. Risk-taking, global diversification, and growth. American Economic Review, 84: 1310-1329.

PATRICK, I.D. \& WARD M.J.D. 1996. International diversification and the portfolio investor. Transactions of the Actuarial Society of South Africa, 11:334-417.

SENDI, I. \& BELLALAH, M. 2010. The equity home bias: Explanations and financial anomalies. International Journal of Economics and Finance, 2(2):78-96.

SHARPE, W.F. 1970. Portfolio theory and capital markets. McGraw-Hill, New York.

SWART, J. 1999. Optimising investment performance through international diversification. ORION, 15:1-24.

SWART, J. 2004. Optimising the global/local equity split. Investment Analysts Journal, 60:39-47.

SWARTZ, J. 2004. Strategic asset allocation - Assessing probabilities of beating absolute return targets. Cadiz Securities Quantitative Research Report.

SPEIDELL, L.S. \& SAPPENFIELD, R. 1992. Global diversification in a shrinking world. Journal of Portfolio Management, 19(1):57-68.

TESAR, L. \& WERNER, I. 1995. Home bias and high turnover. Journal of International Money and Finance, 14:467-492.

VAN DEN HONERT, R.C. \& AFFLECK-GRAVES J.F. 1985. International diversification and the South African investor. South African Journal of Business Management, 16:87-91.

VAN DEN HONERT, R.C. 1983. A mathematical approach to the evaluation of international diversification for the South African investor. Unpublished MSc thesis, University of Cape Town.

VAN HEERDEN, J.D. \& KOEGELENBERG, F.J. 2013. Optimal asset allocation strategies for South African pension funds. Journal of Studies in Economics and Econometrics, 37(1):29-53. 